\title{
SURVEI POLA GRUP KRISTALOGRAFI BIDANG RAGAM BATIK TRADISIONAL
}

\author{
A.D.GARNADI \\ S. GURITMAN \\ A. KUSNANTO \\ F. HANUM \\ Departemen Matematika \\ Fakultas Matematika dan IImu Pengetahuan Alam \\ Institut Pertanian Bogor \\ JI Meranti, Kampus IPB Darmaga \\ Bogor 16680 \\ Indonesia
}

\begin{abstract}
Abstrak
Batik merupakan salah satu budaya Indonesia, khususnya di Jawa, yang perlu dikembangkan dan dilestarikan. Banyak produk yang menggunakan batik sebagai komponen utama, antara lain busana, lukisan, dan perlengkapan rumah tangga.

Dalam penelitian tentang grup simetri bidang datar terdapat 17 tipe pola ulangan (kisi satuan) yang dapat membentuk suatu bidang datar Tujuan utama penelitian ini adalah mencari kisi satuan yang membentuk suatu pola batik.

Dalam penelitian ini telah dikumpulkan sejumlah 262 pola batik yang terdapat dalam batik dengan pola geometris dan nongeometris. Batik dengan pola geometris tersusun dari unsur-unsur seperti lingkaran, segiempat, segitiga dan sebagainya. Kebanyakan dari pola geometris ini dapat ditentukan kisi satuannya. Beberapa pola yang lain belum dapat ditentukan karena kurangnya informasi dari pola batik tersebut. Batik dengan pola nongeometris tidak dapat ditentukan kisi satuannya, karena tidak ada pengulangan pola. Kisi satuan dari pola batik yang dipelajari mengumpul pada beberapa pola tertentu. Hal ini disebabkan karena kemudahan dari kisi satuan tersebut untuk dibuat dan penglihatan kita yang terbiasa dengan simetri dari kisi satuan tersebut.
\end{abstract}

Kata kunci: grup simetri, grup kristalografi bidang, pola batik tradisional, survei 


\section{PENDAHULUAN}

Batik merupakan salah satu seni budaya Indonesia yang patut dilestarikan dan dikembangkan. Banyak produk yang menggunakan batik sebagai komponen utama, antara lain busana, lukisan, perlengkapan rumah tangga (taplak meja, sarung bantal), dan sebagainya. Hasil karya putra-putri Indonesia ini tidak hanya disukai di negeri sendiri tetapi juga dikenal di banyak negara tetangga. Dengan perkataan lain, batik mempunyai nilai ekonomi yang tinggi di samping nilai keindahannya.

Batik merupakan bentuk motif atau pola dekoratif yang dilukiskan pada bidang datar. Motif atau pola dekoratif tersebut juga sebagai motif batik atau pola batik yang merupakan kerangka gambar yang membentuk batik secara keseluruhan. Motif dapat dibedakan dalam dua golongan besar yaitu:

a. golongan motif yang geometris, yaitu motif-motif yang tersusun atas unsur-unsur bentuk geometri seperti lingkaran, segiempat, segitiga, dan sebagainya;

b. golongan motif nongeometris yaitu motif-motif yang tersusun atas unsur-unsur bentuk nongeometris.

Ada dua unsur berbeda pada batik dengan motif-motif geometris yaitu desain atau motif yang merupakan kreasi dari desainer, dan pola yang merupakan cara pengulangan dari desain atau motif. Secara kasar boleh dikatakan bahwa batik dengan motif-motif geometris merupakan gambar (himpunan titik-titik pada bidang) yang polanya diulangulang sehingga tidak berubah. Secara matematis boleh dikatakan bahwa pengulangan pola adalah suatu transformasi yaitu pergeseran, perputaran, dan pencerminan yang mengakibatkan pola-pola batik tidak berubah.

\section{TINJAUAN PUSTAKA}

\subsection{Grup dan Simetri}

Grup adalah suatu gugus $G$ dengan operasi * pada $G$ yang memenuhi aksiomaaksioma: a) operasi * bersifat asosiatif pada $G$, b) gugus $G$ memuat unsur identitas terhadap *, dan c) setiap anggota $G$ mempunyai unsur invers dalam $G$ terhadap *. Suatu grup dikatakan komutatif jika operasinya bersifat komutatif.

Misalkan $S$ adalah sembarang gugus tidak kosong, dan misalkan $M(S)$ adalah gugus yang beranggotakan semua fungsi bijektif dari $S$ ke $S$. Maka $M(S)$ merupakan grup dengan komposisi fungsi sebagai operasi.

Misalkan $p$ adalah titik tertentu dalam suatu bidang dan $P$ menyatakan gugus semua titik pada suatu bidang. Misalkan $G$ menyatakan gugus yang beranggotakan semua rotasi bidang yang berpusat di $p$. Karena rotasi merupakan fungsi bijektif dari $P$ ke $P$, maka $G$ adalah grup terhadap operasi komposisi fungsi.

Misalkan $S$ adalah gugus yang tidak kosong. Permutasi dari gugus $S$ adalah fungsi bijektif dari $S$ ke $S$. Gugus yang beranggotakan semua permutasi dari $S$ merupakan grup terhadap operasi komposisi. Grup ini dinamakan grup simetri pada $S$, dinotasikan dengan $\operatorname{Sym}(S)$. Secara umum, sembarang grup yang memiliki anggota permutasipermutasi disebut grup permutasi. Dalam hal ini grup permutasi $S$ tidak harus memuat sermua permutasi pada $S$. Jika $S$ adalah gugus $\{1,2, \ldots, n\}$, dengan $n$ bilangan bulat positif, Sym (S) dinotasikan dengan $S_{n}$. 
Misalkan $H$ adalah anak gugus grup $G$. $H$ disebut subgrup dari $G$ jika dan hanya jika $H$ juga merupakan grup terhadap operasi yang sama dengan $G$. Misalkan $G$ adalah grup, $a \in G$, dan $\langle a\rangle$ menyatakan gugus yang beranggotakan semua kuasa dari $a$, yang ditulis $\langle a\rangle=\left\{a^{n} \mid n \in Z\right\}$. Maka $\langle a\rangle$ merupakan subgrup dari $G$ dan dinamakan subgrup yang dibangun oleh $a$. Jika $H$ adalah subgrup dan $H=\langle a\rangle$ untuk suatu $a \in H$, maka $H$ disebut subgrup siklik.

Banyak grup yang timbul dari keterkaitannya dengan simetri. Seperti halnya bilangan yang dapat digunakan untuk menentukan ukuran, grup dapat digunakan untuk mengukur simetri. Setiap gambar bidang yang dikaitkan dengan suatu grup, grup tersebut memberikan sifat padanya. Aplikasi dari teori grup ini merupakan perluasan dari geometri ke kristalografi.

\subsection{Transformasi}

Misalkan $P$ menyatakan gugus semua titik pada suatu bidang, dan $M$ menyatakan gugus semua permutasi dari $P$ yang mempertahankan jarak di antara titik-titiknya. Jadi, jika $p$ dan $q$ adalah dua titik dalam $P$, dan $m$ adalah permutasi di $M$, maka jarak antara $m(p)$ dan $m(q)$ adalah sama dengan jarak antara $p$ dan $q$. Permutasi-permutasi dalam $\mathrm{M}$ tersebut dinamakan isometri atau motion (pergerakan) pada bidang. Berikut ini diperkenalkan tiga tipe isometri, yaitu rotasi (perputaran), refleksi (pencerminan), dan translasi (pergeseran).

Jika $P$ adalah suatu titik tertentu dalam suatu bidang, maka rotasi bidang berpusat di $P$ merupakan isometri bidang. Suatu transformasi dengan perputaran memindahkan setiap titik $P$ ke $P$ ' sehingga $A P^{\prime}$ adalah $A P$ yang diputar sebesar $\theta$ dengan titik pusat $A$. Suatu perputaran sejauh $360 \%$ yang mengakibatkan gambar tidak berubah dikatakan mempunyai pusat putaran lipat- $n$ dengan $n$ merupakan bilangan bulat.

Jika $P$ suatu titik dan I suatu garis sembarang maka pencerminan (refleksi) titik $P$ pada I menghasilkan $P^{\prime}$ sehingga jarak $P$ dengan garis I sama dengan jarak $P^{\prime}$ dengan garis $\ell$ dan juga $P P^{\prime}$ memotong tegak lurus garis $\mathrm{I}$.

Pergeseran (translasi) pada bidang $P$ adalah suatu pemetaan dari setiap titik pada jarak dan arah yang sama.

Jika $\underline{t}$ adalah sembarang vektor pada bidang, didefinisikan translasi TT menjadi suatu transformasi yang memetakan $P$ ke $P$ ', sehingga $P P^{\prime}=\underline{t}$.

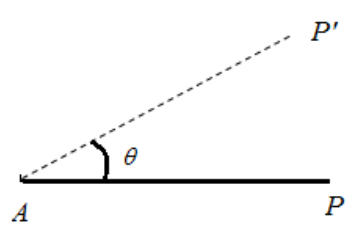

(a)

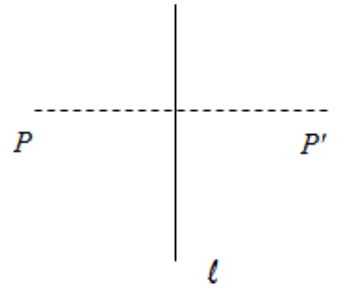

(b)

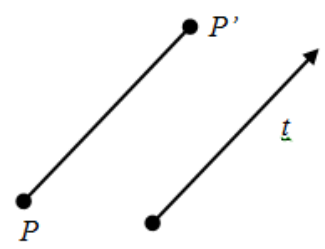

(c)

Gambar 1 (a) Perputaran, (b) pencerminan, (c) pergeseran

Jika $M$ adalah gugus yang beranggotakan semua isometri pada suatu bidang $P$, maka $M$ merupakan subgrup dari $\operatorname{Sym}(P)$. Dengan demikian $M$ merupakan grup terhadap operasi komposisi.

Suatu pengembangan atau perpaduan dari pergeseran dan pencerminan akan menghasilkan suatu transformasi baru yang disebut pantul geser (glide reflection). 


\section{METODE PENELITIAN}

Metode penelitian yang digunakan mencakup langkah-langkah berikut :

1. studi eksplorasi terhadap:

a. pola-pola batik yang ada dan diskusi pakar (perancang dan peneliti) batik,

b. penggunaan grup simetri melalui pustaka (buku dan jurnal) dan diskusi pakar dalam bidang aljabar,

2. survey batik ke lembaga seni rupa atau pengusaha batik,

3. penelusuran penyebab pengelompokan pola ulangan melalui wawancara dengan pakar batik,

4. membuat suatu rancangan batik baru dengan pola-pola simetri yang digunakan.

\section{PEMBAHASAN}

\subsection{Grup Kristalografi}

Jika poligon-poligon yang kongruen dengan sisi-sisinya tidak saling overlap ditata, maka yang memenuhi bidang hanyalah segi empat, segitiga dan heksagonal (segi enam) seperti terlihat pada Gambar 2 berikut. Suatu bidang yang luas dapat diisi dengan poligon-poligon yang kongruen ini sehingga seluruh bidang terisi (tidak berlubang) dengan melakukan perputaran, pencerminan, pergeseran atau translasi terhadap poligon-poligon tersebut. Dengan cara ini akan didapatkan pola-pola simetri tertentu.
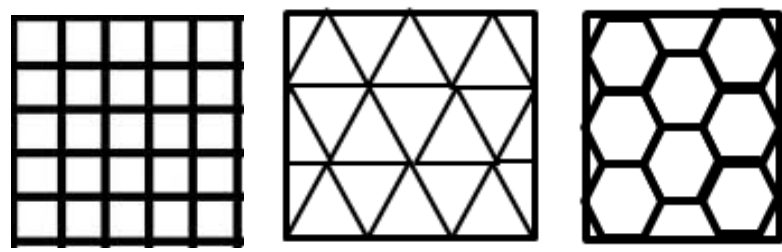

Gambar 2. Poligon pengisi bidang.

Grup yang berhubungan dengan masalah ini disebut grup simetri. Dalam hal ini terdapat 17 grup yang memenuhi kriteria tersebut. Ke-17 grup ini sering disebut sebagai grup kristalografi dua dimensi. Grup kristalografi ini merupakan grup simetri. Poligon terkecilnya disebut sebagai kisi satuan (lattice).

\subsection{Kisi Satuan}

Pada bab ini akan dibahas bahwa setiap pola ulangan memiliki gabungan dari titik-titik yang menjadi suatu kisi. Ambil sembarang titik di pola. Kisinya adalah himpunan dari bayanganbayangan titik-titik yang diakibatkan pergeseran dari sekelompok pola. Sebuah kisi satuan adalah sebuah jajaran genjang yang setiap titik sudutnya merupakan titik kisi. Vektor yang membentuk sisi dari sebuah kisi satuan dihasilkan dari pergeseran sekelompok pola. (Para ahli menggunakan istilah sel primitif untuk sebuah kisi satuan, beberapa yang lain menggunakan istilah sel satuan atau sel.) Di samping pergeseran, sebuah pola ulangan mungkin juga dipetakan kepada dirinya sendiri dengan beberapa isometri bidang: perputaran, pencerminan, dan pantul geser.

Grup isometri dari pola adalah himpunan dari seluruh isometri yang memetakan suatu pola atas dirinya sendiri. Grup simetri dari sebuah pola ulangan memetakan suatu gabungan kisi atas dirinya sendiri. Sebuah kisi satuan dapat memiliki lebih dari satu pusat putaran lipat- $n$. Sebuah kisi satuan dikatakan mempunyai orde- $n$ jika mempunyai pusat putaran lipat- $n$ yang 
tertinggi. Menurut Doris Schattschneider, terdapat lima tipe kisi satuan yang berbeda, yaitu jajaran genjang, persegi pajang, belah ketupat, bujur sangkar, dan heksagonal (yang tersusun dari dua segitiga sama sisi) seperti terlihat pada Gambar 3 berikut.

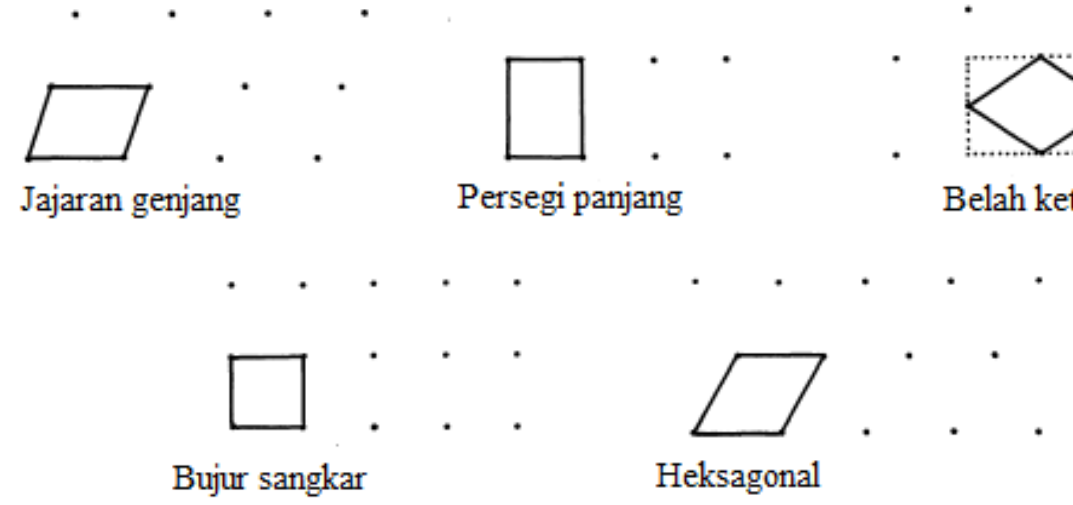

Gambar 3. Lima tipe kisi satuan.

Setiap jenis kisi satuan dapat membentuk pola dengan bantuan suatu transformasi tertentu. Menurut Schattschneider, terdapat 17 tipe grup kristalografi berbeda yang dapat dilihat pada Gambar 4 berikut.

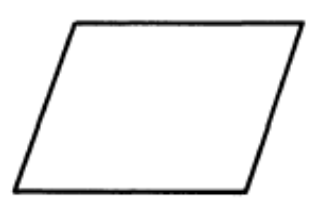

$p 1$

(p1)

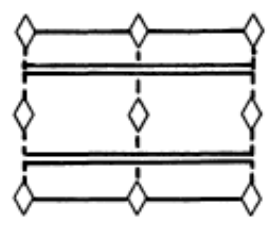

pmg

(p2mg)

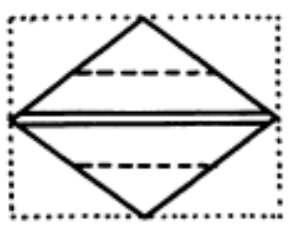

$\mathrm{cm}$

(c1m1)

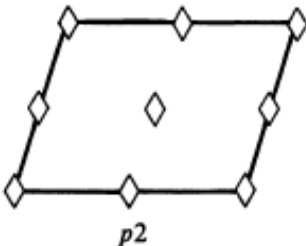

(p211)

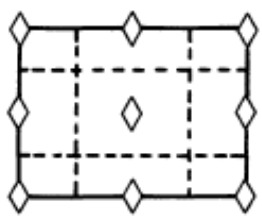

pgg

(p2gg)

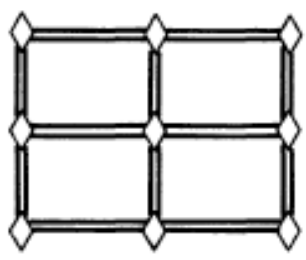

pmm

(p2 $2 \mathrm{~mm})$

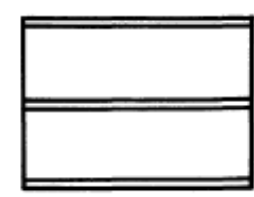

pm

(plml)

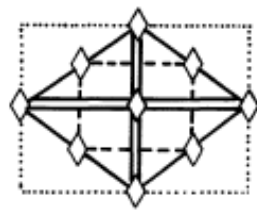

$\mathrm{cmm}$

(c2 $2 \mathrm{~mm})$

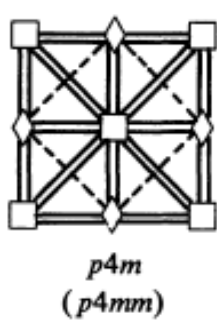

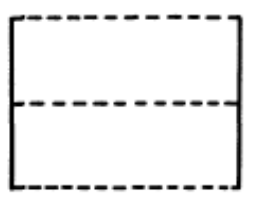

pg

(plg1)
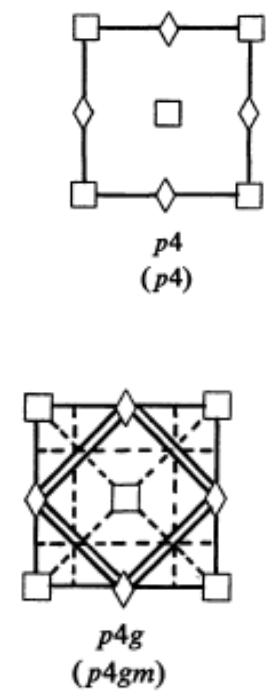

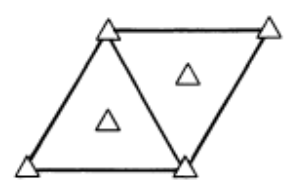

$p 3$
$(p 3)$

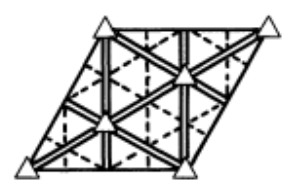

$p 3 m 1$ (p3m1)

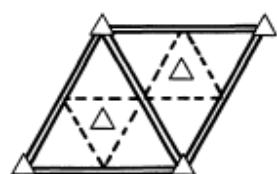

p31 $\mathrm{m}$

(p31m)

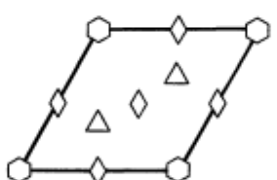

p6

(p6)

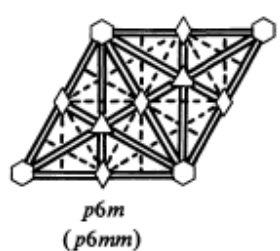

(p6mm) 


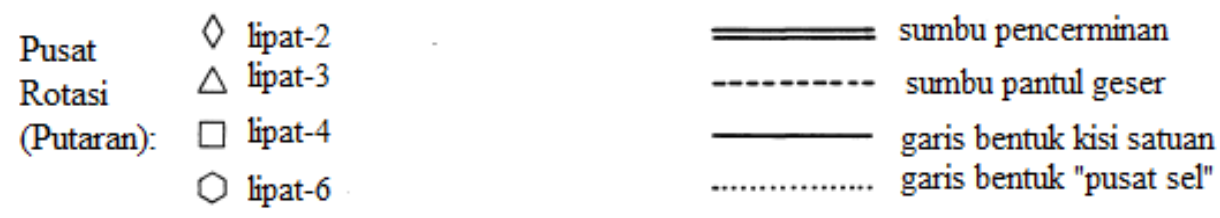

Gambar 4. Grup kristalografi 2 dimensi

Dalam penggolongan tersebut terdapat beberapa notasi, antara lain:

1. Huruf $p$ dan $c$ menyatakan sel primitif (kisi satuan) atau sel terpusat. Pada umumnya sel primitif mempunyai pusat-pusat dengan orde perputaran tertinggi berada pada titik-titik kisi, sedangkan sel terpusat mempunyai sumbu pencerminan yang tegak lurus dengan satu atau dua sisi sel.

2. Bilangan bulat $n$ menunjukkan orde atau tingkat perputaran yang tinggi.

3. Simbol yang menunjukkan bahwa sumbu simetri tegak lurus dengan sumbu- $x$ dari sel (yaitu sisi kiri dari sel) ialah $m$ (mirror) menyatakan sumbu pencerminan, $g$ menyatakan tidak ada pencerminan melainkan sumbu pantul geser (glide reflection).

4. Simbol yang menunjukkan sebuah sumbu simetri pada sudut a terhadap sumbu $x$, dengan $\alpha$ bergantung pada $n$, orde atau tingkat perputaran yang tertinggi: $\alpha=180^{\circ}$ untuk $n=1$ atau $n=2, \alpha=45^{\circ}$ untuk $n=4, \alpha=60^{\circ}$ untuk $n=3$ atau $n=6$.

Untuk mengklasifikasikan suatu pola ke dalam salah satu model dari 17 kisi satuan, berikut ini disediakan daftar untuk mengenali pola bidang ulang.

Tabel $1 . \quad$ Ciri pola-pola ulangan

\begin{tabular}{|c|c|c|c|c|c|}
\hline $\begin{array}{l}\text { Model } \\
\text { Kisi } \\
\text { Satuan }\end{array}$ & Kisi & Orde & Pencerminan & $\begin{array}{l}\text { Pantul } \\
\text { Geser }\end{array}$ & Keterangan \\
\hline$p 1$ & jjg & 1 & tidak ada & tidak ada & \\
\hline$p 2$ & jjg & 2 & tidak ada & tidak ada & \\
\hline$p m$ & ppj & 1 & ada & tidak ada & \\
\hline$p g$ & ppj & 1 & tidak ada & ada & \\
\hline $\mathrm{cm}$ & bkt & 1 & ada & ada & \\
\hline$p m m$ & ppj & 2 & ada & tidak ada & \\
\hline$p m g$ & ppj & 2 & ada & ada & $\begin{array}{l}\text { sumbu } \\
\text { simetri } \\
\text { sejajar }\end{array}$ \\
\hline$p g g$ & ppj & 2 & tidak ada & ada & \\
\hline $\mathrm{cmm}$ & bkt & 2 & ada & ada & $\begin{array}{l}\text { sumbu } \\
\text { simetri saling } \\
\text { tegak lurus }\end{array}$ \\
\hline$p 4$ & bks & 4 & tidak ada & tidak ada & \\
\hline$p 4 m$ & bsk & 4 & ada & ada & $\begin{array}{l}\text { pusat-4 pada } \\
\text { sumbu } \\
\text { cermin }\end{array}$ \\
\hline$p 4 g$ & bsk & 4 & ada & ada & $\begin{array}{l}\text { pusat-4 tidak } \\
\text { pada sumbu } \\
\text { cermin }\end{array}$ \\
\hline p3 & hks & 3 & tidak ada & tidak ada & \\
\hline$p 3 m 1$ & hks & 3 & ada & ada & $\begin{array}{l}\text { semua pusat- } \\
3 \quad \text { pada }\end{array}$ \\
\hline
\end{tabular}




\begin{tabular}{|c|c|c|c|c|c|}
\hline & & & & & $\begin{array}{l}\text { sumbu } \\
\text { cermin }\end{array}$ \\
\hline$p 3 m 1$ & hks & 3 & ada & ada & $\begin{array}{l}\text { tidak semua } \\
\text { pusat-3 pada } \\
\text { sumbu } \\
\text { cermin }\end{array}$ \\
\hline$p 6$ & hks & 6 & tidak ada & tidak ada & \\
\hline$p 6 m$ & hks & 6 & ada & ada & \\
\hline
\end{tabular}

Keterangan :

jjg : jajaran genjang, bsk : bujur sangkar,

ppj : persegi panjang, hks : heksagonal

bkt : belah ketupat

\subsection{Algoritme Penentuan Tipe Kisi Satuan}

Telah diketahui bahwa setiap pola geometris pasti mempunyai pola ulangan yang merupakan salah satu dari ketujuh belas kisi satuan yang ada, demikan pulalah halnya dengan batik yang mempunyai pola geometris. Untuk dapat menggolongkan setiap pola batik dengan pola geometris ke dalam salah satu dari ketujuh belas kisi satuan yang ada, maka digunakan algoritme Durbin (1985) yang dapat disarikan sebagai berikut.

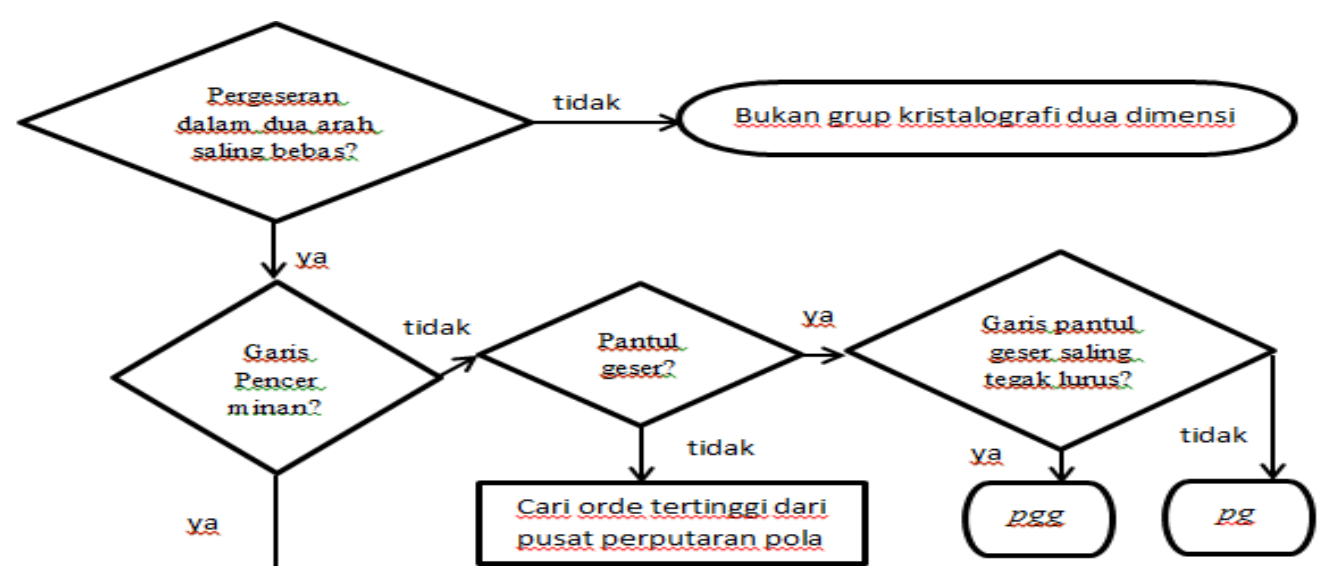

Gambar 5. Algoritme penentuan kisi satuan. 


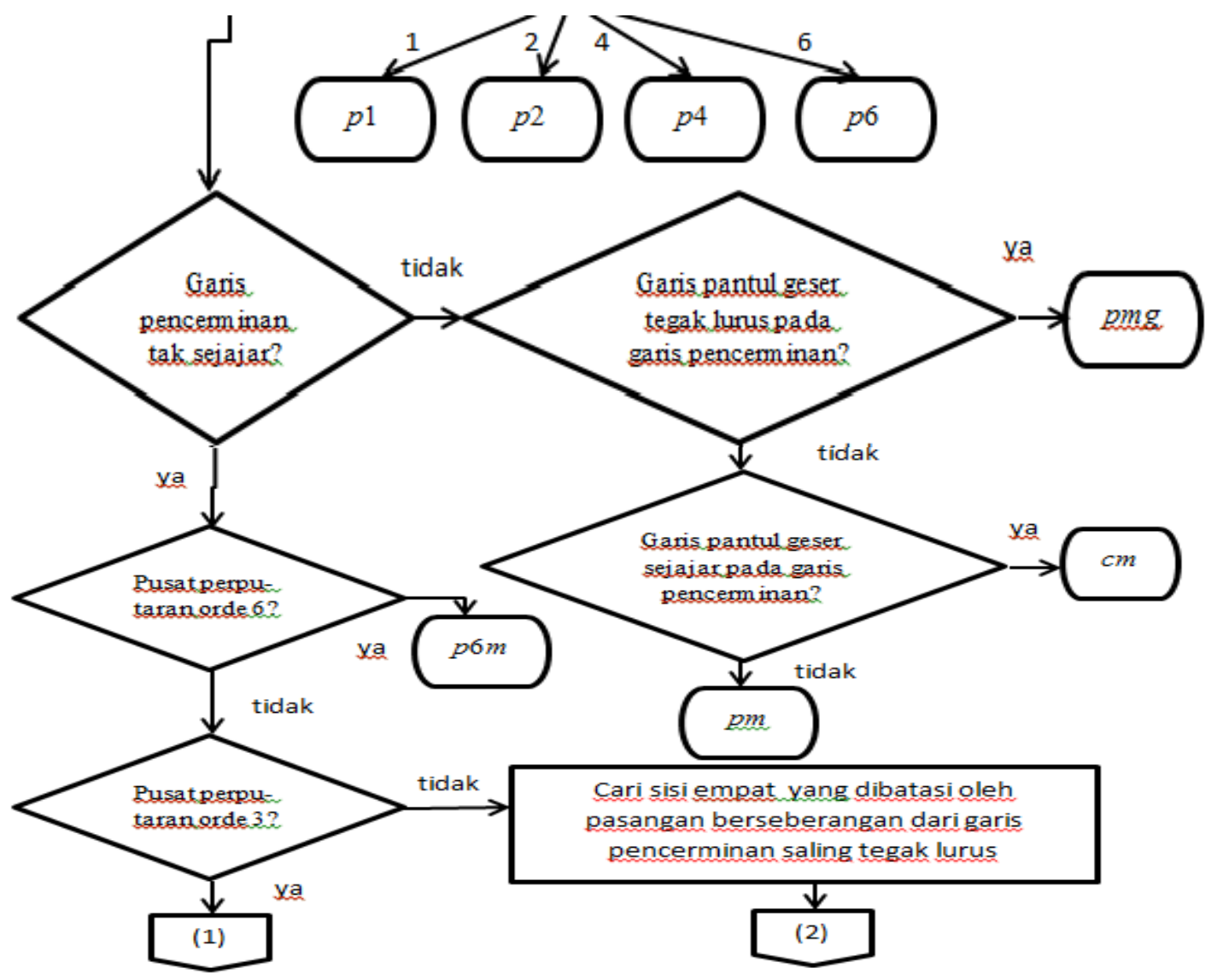

(1)

$\downarrow$

Cari 3 pasang garis pencerminan tak sejajar sehingga tak ada garis pencerminan yang memotong segitiga sama sisi yang dibangunnya

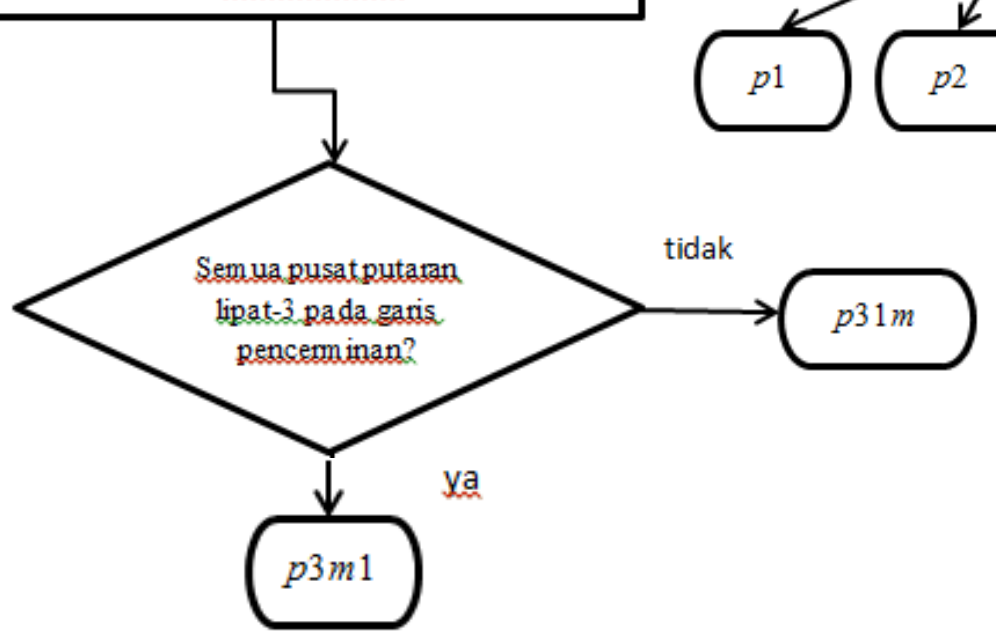

(2)

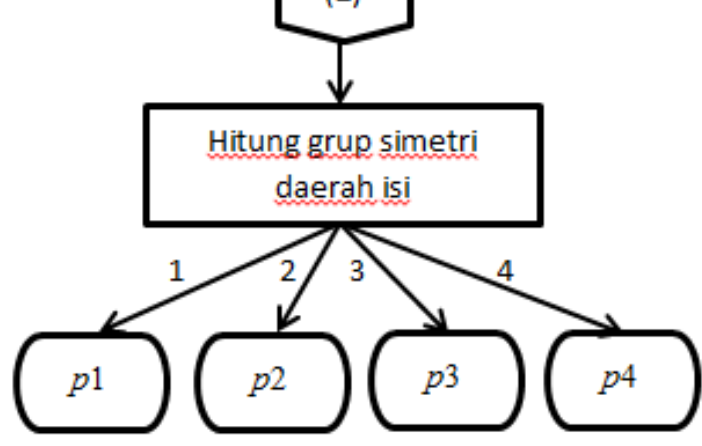

Gambar 6. Algoritme penentuan kisi satuan (lanjutan). 


\subsection{Klasifikasi Pola Batik Nusantara}

Dalam penelitian ini, hanya sebagian motif/pola batik yang dianalisis yaitu sebanyak 272 pola batik yang tersebar di seluruh penjuru Nusantara. Pola batik tersebut diambil dari (Hamzuri 1989) dan (Djumena 1990). Dari hasil pengklasifikasian, diperoleh tabel berikut ini.

Tabel 2. Tipe kisi satuan

\begin{tabular}{lcc}
\hline Kisi & Jumlah Pola & Persentase (\%) \\
\hline$p 4 m$ & 72 & 40.00 \\
$p m$ & 27 & 15.00 \\
$p 1$ & 25 & 13.89 \\
$p 2$ & 24 & 13.33 \\
$\mathrm{cmm}$ & 13 & 7.22 \\
$p m m$ & 9 & 5.00 \\
$p 4 g$ & 3 & 1.67 \\
$\mathrm{~cm}$ & 3 & 1.67 \\
$p m g$ & 2 & 1.11 \\
$p 4$ & 2 & 1.11 \\
\hline Total & 180 & \\
\hline
\end{tabular}

Dari Tabel 2 terlihat bahwa kisi satuan terbanyak yang muncul ialah $p 4 m$, dan hanya 180 $(66.2 \%)$ pola batik yang dapat diklasifikasikan berdasarkan grup kristalografi dua dimensi; pola batik selebihnya bukan merupakan pola bidang ulangan. Berikut ini diberikan beberapa di antaranya.

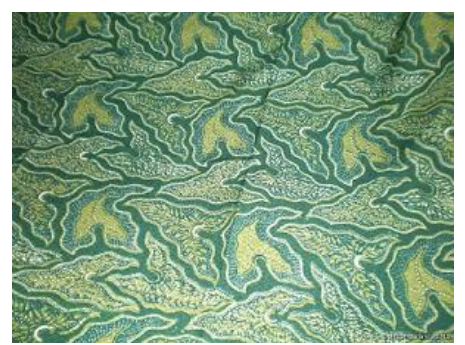

Motif: Godong Lumbu

Tipe kisi satuan: $p 1$

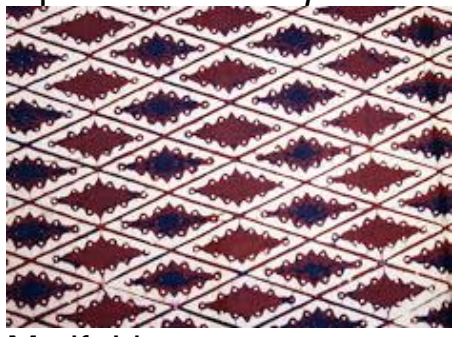

Motif: Limaran

Tipe kisi satuan: pmm

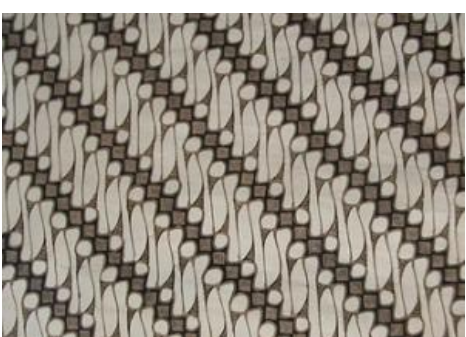

Motif: Parang Rusak

Tipe kisi satuan: $p 2$

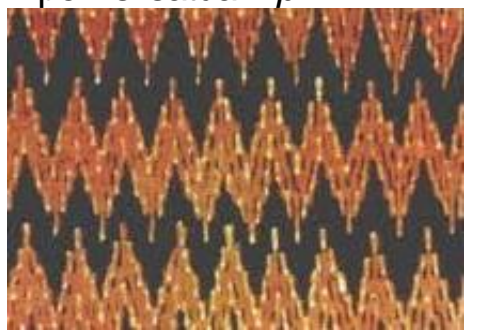

Motif: Tirta Teja

Tipe kisi satuan: pmg

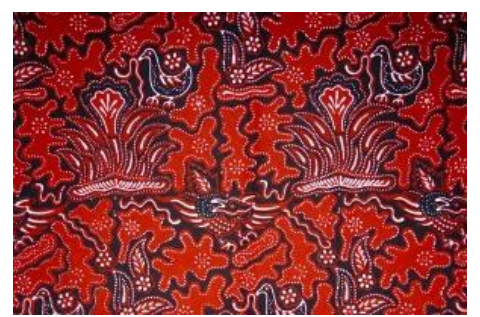

Motif: Jahe Serimpang

Tipe kisi satuan: $p m$

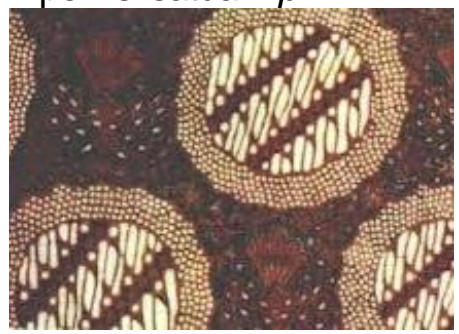

Motif: Parang Kurung

Tipe kisi satuan: $\mathrm{cmm}$ 


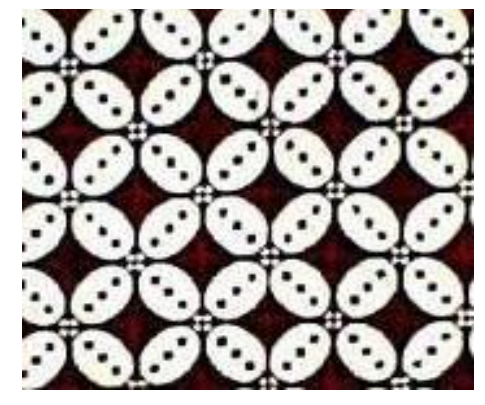

Motif: Kawung Benggol

Tipe kisi satuan: $p 4 m$

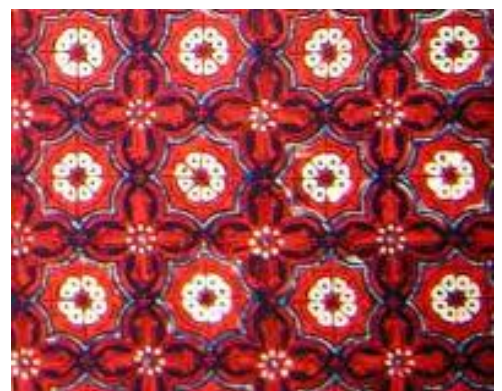

Motif: Ceplok Ganggong Tipe kisi satuan: $p 4 m$

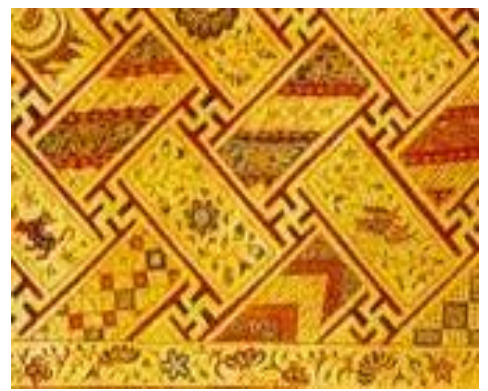

Motif: Banji

Tipe kisi satuan: $p 4 g$

Gambar 7. Contoh pola/motif batik Indonesia dan tipe kisi satuannya

\section{SIMPULAN}

Pola/motif batik di Indonesia dapat dipandang sebagai gambar atau himpunan titik-titik pada bidang yang polanya diulang-ulang dengan cara: pergeseran, perputaran, pencerminan, atau pantul geser. Setiap pola ulangan pada pola batik akan terdapat suatu daerah terbatas sebagai pola dasarnya, mempunyai pergeseran garis lurus yang saling bebas dan terdapat pergeseran dengan vektor terpendek yang memetakan pola pada dirinya sendiri.

Setiap pola ulangan pada motif batik akan membentuk sebuah kisi. Dari lima tipe kisi (yaitu: jajaran genjang, persegi panjang, belah ketupat, bujur sangkar, dan heksagonal) bila dilihat berdasarkan grup simetri bidang yang dimilikinya, maka akan diperoleh 17 tipe grup kristalografi dua dimensi yang masing-masing mempunyai unsur kisi satuan berbeda. Untuk menggambar batik keseluruhan atau secara utuh cukup hanya mengetahui pola dasar beserta kisi satuannya, kemudian dengan cara transformasi isometri akan diperoleh suatu motif batik baru.

Dari penelitian ini, terlihat bahwa batik-batik di Indonesia masing mengumpul pada suatu pola tertentu, untuk itu masih dapat dikembangkan pola batik baru sehingga pola/motif batik Indonesia menjadi lebih kaya dan beragam.

\section{DAFTAR PUSTAKA}

[1]. N.S. Djumena, Batik dan Mitra. Jakarta, Djambatan, 1990.

[2]. J.R. Durbin, Modern Algebra: An Introduction. 2nd ed. New York, Wiley, 1985.

[3]. Hanzuri, Batik Klasik, Jakarta, Djambatan, 1981.

[4]. D. Schattschneider. "The plane symmetry groups: Their Recognition and Notation", American Mathematical Monthly, vol. 85, no. 6, pp. 430 - 450, 1978.

Pengutipan:

A.D.GARNADI, S. GURITMAN, A. KUSNANTO, DAN F. HANUM, SURVEI

POLA GRUP KRISTALOGRAFI BIDANG RAGAM BATIK TRADISIONAL, Jurnal Matematika dan Aplikasinya, VOL. 11, NO. 2, DESEMBER, 2012, 1-10 